\title{
The influence of a toxic cyanobacterial bloom and water hydrology on algal populations and macro- invertebrate abundance in the upper littoral zone of Lake Krugersdrift, South Africa
}

\author{
Paul J. Oberholster ${ }^{1}$, Anna-Maria Botha ${ }^{2}$ and Peter J. Ashton ${ }^{1}$
}

(1) CSIR Natural Resources and the Environment, PO Box 395, Pretoria, ZA0001, South Africa

(2) Department of Genetics, University of Pretoria, Hillcrest, Pretoria, ZA002, South Africa

Paul J. Oberholster

Email: anna.oberholster@up.ac.za

\begin{abstract}
The biological interactions and the physical and chemical properties of the littoral zone of Lake Krugersdrift were studied for a 4-month period when a dense, toxic cyanobacterial bloom dominated by Microcystis aeruginosa was present in the main lake basin. The presence of a toxic strain of $M$. aeruginosa was confirmed through the use of ELISA and molecular markers that detect the presence of the mcyB and mcyD genes of the mcy gene cluster that synthesizes microcystin. An increase in Microcystis toxicity at sites dominated by the cyanobacterial scum was accompanied by an increase in total abundance of the macroinvertebrate families Hirudinae, Chironomidae, and Tubificidae. Sites located away from the cyanobacterial scum had a lower abundance but a higher diversity of macroinvertebrates. The water quality under the Microcystis scum was characterized by low $\mathrm{pH}$ values, low concentrations of dissolved oxygen, and lower total alkalinity values. The periphytic alga

Ulothrix zonata was absent in areas dominated by the cyanobacterial scum, possibly as a result of overshadowing by the scum or direct toxic allelopathic effects on growth and photosynthesis. The diatom Diatoma vulgare dominated the benthic algal flora beneath the cyanobacterial scum.
\end{abstract}

\section{Introduction}

As it has occurred in most countries in the world e.g., Australia, USA, and China, (Oberholster et al. 2005a) the incidence of cyanobacterial blooms in South African water bodies has increased during recent years as a result of a progressive increase in the eutrophication of rivers and water storage reservoirs (Van Ginkel et al. 2000). Urban and industrial complexes in South Africa generate large quantities of sewage and, even when these are treated, the effluents still contain high concentrations of 
dissolved salts and nutrients. Because South Africa is classified as a water scarce country, the National Water Act (Republic of South Africa 1998) requires treated effluent to be discharged into river courses to augment existing water supplies and be re-used. As a result, the volume of treated and untreated effluent in several South African rivers now exceeds the normal flow of water prior to effluent discharge and many water storage reservoirs are now eutrophic or hypertrophic (Van Ginkel et al. 2001). Nutrients and other agro-chemicals contained in return flows and seepage from irrigated agriculture aggravates this situation (Pitois et al. 2001).

When nutrient-rich effluent enters an artificial lake or reservoir, it stimulates rapid growth of phytoplankton species and aquatic macrophytes and, in extreme cases, leads to the development of mono-specific blooms of cyanobacteria. (NIWR (National Institute for Water Research) 1985; Oberholster et al. 2005a). Harmful cyanobacterial blooms in South African lakes are typically characterized by heavy biomass accumulations that often consist of a single or a few species, usually members of the genera Microcystis and Anabaena (Van Ginkel 2004). These species can persist for long periods in hypertrophic impoundments (NIWR 1985) and are associated with total microcystin concentrations of $>100 \mu \mathrm{g} / \mathrm{l}$ for more than $50 \%$ of the time (Van Ginkel et al. 2000). Blooms of cyanobacteria in rivers, lakes, and reservoirs disrupt the normal patterns of phytoplankton succession, decrease phytoplankton diversity, and alter virtually all of the interactions between organisms within the aquatic community - from viruses through zooplankton to fish (Figueredo and Giani 2001). One of the most serious effects of cyanobacterial blooms is the production of harmful secondary metabolites that have serious adverse effects on the health and vitality of humans and animals (Wiegand and Pflugmacher 2005).

Hepatotoxic microcystins are reported to be the most frequently occurring toxins produced by cyanobacteria (Carmichael 1994). Microcystins exert their potent toxic effect by being specific inhibitors of protein phosphatases 1 and 2A, two of the major serine and threonine protein phosphatases involved in eukaryotic cell regulation (MacKintosh et al. 1990). While several studies have addressed the issue of cyanobacterial toxicity to laboratory animals (e.g., Beattie et al. 2000; Chong et al. 2002), few studies (Wiegand and Pflugmacher 2005; White et al. 2005; Rondel et al. 2008) have focused on the ecological effects of cyanobacterial blooms in lakes. Hence, there exists a great knowledge gap especially on the effects of cyanobacterial toxins on the natural macroinvertebrate fauna and phytoplankton in turbid eutrophic lakes. In our study, we examined changes in the littoral macroinvertebrate and phytoplankton communities as well as the physico-chemical parameters of Lake Krugersdrift, South Africa, during the summer months of 2005-2006. Our study focused on the progression of a cyanobacterial bloom dominated by Microcystis aeruginosa and we evaluated the wide-ranging effects of the cyanobacterial toxins produced by the bloom on the Lake Krugersdrift littoral ecosystem.

\section{Material and methods}

\section{Study area}

The centre point of the dam wall that impounds Lake Krugersdrift on the Modder River is located at $28^{\circ} 57^{\prime} 00^{\prime \prime} \mathrm{S}$ and $25^{\circ} 57^{\prime} 30^{\prime \prime} \mathrm{E}$, approximately $42 \mathrm{~km}$ northwest of 
the city of Bloemfontein in the Free State Province, South Africa (Fig. 1). The dam wall is approximately $5 \mathrm{~km}$ in length - spanning a wide, shallow valley - and was completed in 1970. The impoundment was built to provide water primarily for downstream irrigation agriculture along the Modder River, and the lake is now also used for several recreational activities, including sport angling, swimming, yachting, and power boating.

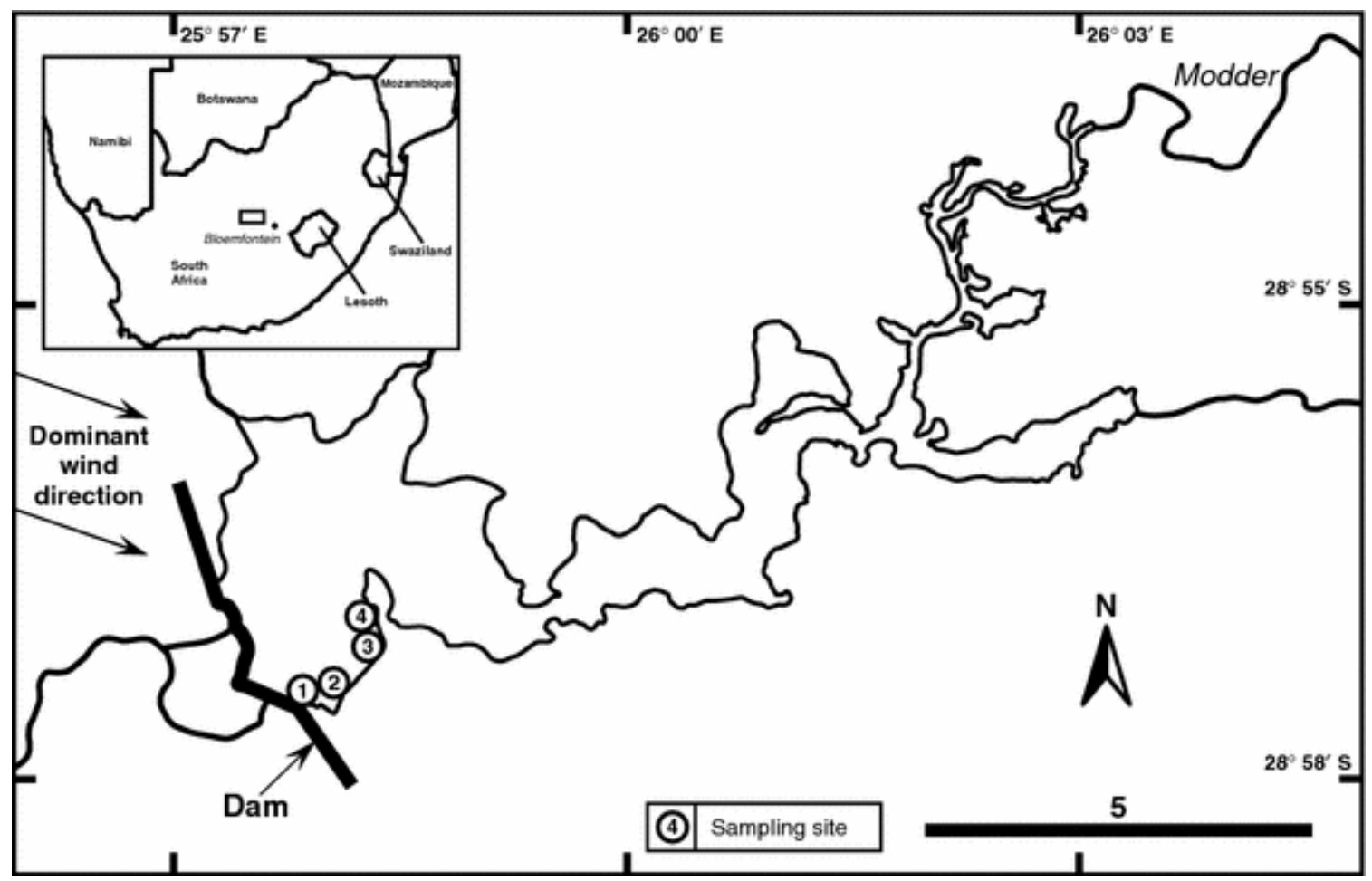

Fig. 1 Map of Lake Krugersdrift, showing the location of four sampling sites close to the dam wall, the positions of inflowing rivers and streams, and the dominant wind direction. Inset shows the location of the map area in South Africa

The impounded water body has a maximum depth of $18.3 \mathrm{~m}$, an average depth of $4.5 \mathrm{~m}$ (Grobbelaar 1992), and a surface area of $18.53 \mathrm{~km}^{2}$ when full. The reservoir receives an average inflow of approximately 159 million $\mathrm{m}^{3}$ each year via the Modder River, resulting in a hydraulic residence time of approximately 0.475 years. In 1970, the full supply capacity of Lake Krugersdrift was 83.574 million $\mathrm{m}^{3}$. Routine sedimentation surveys conducted by the Department of Water Affairs and Forestry indicate that sediment accumulation in the reservoir has reduced the lake's usable volume by approximately $0.7 \%$ per year. The resulting full supply capacity of the lake in 2005 (when samples were first collected for this study) was 65.418 million $\mathrm{m}^{3}$. This indicates that sediment accumulation has reduced the lake's water holding capacity by $22 \%$ during the 35 -year period since construction was completed. By 2005 , accumulated sediment had reduced the average depth of Lake Krugersdrift to $3.53 \mathrm{~m}$, while the hydraulic residence time had decreased to 0.41 years.

Lake Krugersdrift has a catchment area of $6,331 \mathrm{~km}^{2}$ and the Modder River is the main inflowing river to the lake. As its name implies (the English translation of the name Modder River is "mud river") and, as confirmed by sedimentation surveys, the 
Modder River is turbid and conveys large volumes of suspended sediment (10100 metric tonnes $\mathrm{km}^{-2}$ ) from the catchment into Lake Krugersdrift (Grobbelaar 1985). The main types of land use in the catchment of Lake Krugersdrift are crop production by irrigated and dryland agriculture, with smaller areas of beef, dairy, and wildlife farming. At present there is limited information on seasonality of phytoplankton within Lake Krugersdrift. The only information was reported by Grobbelaar (1992) that observed maximum chlorophyll and maximum production rate (Pmax) in the summer months with generally lower rates during winter (MaySeptember).

Lake Krugersdrift is situated downstream of Bloemfontein and the inflowing Modder River receives urban runoff and treated domestic and industrial effluent from the city. These effluents have been linked to the eutrophication and sporadic incidents of cyanobacterial blooms in the water of Lake Krugersdrift. One such incident occurred in December 2004 when mass mortalities of adult fish (Barbus kimberleyensis,

Barbus aeneus, and Labeo capensis) were associated with the degradation of a toxic cyanobacterial bloom during a period of low water levels, which resulted in high $\mathrm{pH}$ values $(>8.5)$ and low concentrations $(<1 \mathrm{mg} / \mathrm{l})$ of dissolved oxygen (BothaOberholster and Oberholster 2007) (Fig. 2).

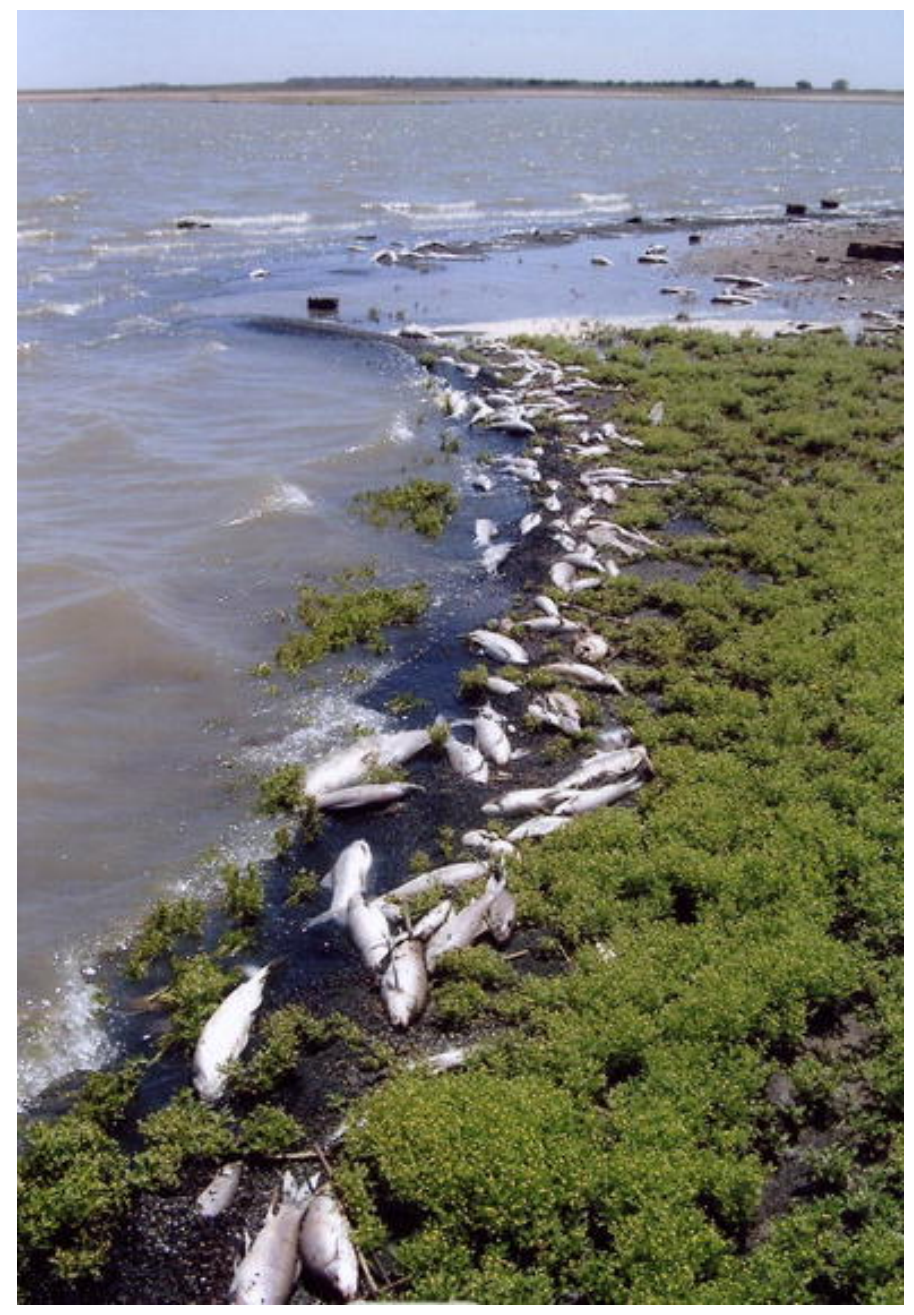


Fig. 2 Photograph of a portion of the Lake Krugersdrift shoreline showing turbid lake water and dead adult fish stranded along the shoreline during an extensive fish kill in December 2004

Samples of water, sediment, and cyanobacteria were collected from four sampling sites (Fig. 1) at 2-weekly intervals - from November 2005 to February 2006 - the mid-summer period when cyanobacterial blooms are most commonly present in Lake Krugersdrift.

\section{Sampling of macroinvertebrates and phytobenthos}

For the collection of macroinvertebrate and phytobenthos samples, two sites were selected within the upper littoral zone $(<1.5 \mathrm{~m}$ deep) of the lake on the south-western shoreline of the embayment close the dam wall (sites 1 and 2 in Fig. 1). These two sites were selected because this area was partly sheltered from the prevailing winds and remained covered with a layer of $M$. aeruginosa surface scum $(\approx 2.5 \mathrm{~cm}$ thick) for up to 4 months each year. Two additional control sites were chosen on the southeastern shoreline of the same embayment (sites 3 and 4 in Fig. 1). These control sites were slightly more exposed to the prevailing winds and the cyanobacterial bloom was absent. Microscopic checks (at 1,250× magnification under an Olympus inverted light microscope) of water samples from the control sites revealed very low numbers of $M$. aeruginosa cells ( $\leq 425$ cell/1) throughout the study period. The substrate composition and structure at the four sampling sites appeared visually to be similara mixture of fine sand and coarse silt with some organic debris at the surface, and scattered calcrete pebbles.

Macroinvertebrates were collected from November 2005 to February 2006 from the surface sediments at each sampling site with a pond net $(25 \mathrm{~cm}$ diameter; $500 \mu \mathrm{m}$ mesh), by pushing the net through the loose upper part (1-2 cm) of the substrate over a distance of $1 \mathrm{~m}$. A random sampling procedure was used to reduce hydrobiological variability between sites (Voelz and Ward 1991). Samples were immediately preserved in $70 \%$ ethanol and later washed through a $75 \mu \mathrm{m}$ mesh sieve to remove fine particles. The samples were then sorted and identified according to Merrit and Cummins (1996) to the lowest possible taxonomic category under an Olympus dissection microscope. Sorting continued until at least 300 individuals were counted, or the entire sample was sorted. Invertebrate diversity was calculated using the Shannon's diversity index (Shannon and Weaver 1949):

$H=-\left(\sum(\rho \mathrm{g} n)\right.$

where $\rho_{i}$ is the proportion of the total number of specimens, I, expressed as a proportion of the total number of species for all species present in the ecosystem. The product of $\rho_{i} \ln \rho_{i}$ for each species in the aquatic ecosystem is summed, and multiplied by -1 to give $H$. The Berger-Parker dominance index (Berger and Parker 1970) was used to measure the evenness or dominance of organisms at each site:

$D=N_{\max } / N$

where $N_{\max }=$ the number of individuals of the most abundant species present in each sample, and $N=$ the total number of individuals collected at each site. In addition, an alternate classification technique that involved the functional analysis of invertebrate feeding based on their morpho-behavioral mechanisms of food acquisition, was also used (Merrit and Cummins 1996). The functional feeding groups consisted of 
"scrapers" which remove periphytic material, "shredders" which ingest coarse particulate organic matter, "predators" which eat living animals, "collectors", which consume decomposing fine particulate organic matter, and the last group which was divided into "collector-gatherers", which collect fine particulate organic matter from the sediment, and "collector-filterers", which collect fine particulate organic matter from the water column.

Substrate (sediment) samples were collected from each sampling site with a steel corer (5 cm diameter), which was driven into the substrate to an approximate depth of $10 \mathrm{~cm}$. The material within the corer was removed by hand and macroinvertebrates, organic matter and the remaining water were passed through a $75 \mu \mathrm{m}$ mesh sieve. The sediment water was fixed with buffered $5 \%(\mathrm{v} / \mathrm{v})$ formaldehyde for determination of phytobenthos composition, community structure, and identification of the algal species present. A total of 50-100 ml of each of the samples were sedimented in chambers and were analysed under an inverted microscope at 1,250× magnification using the strip-count method (American Public Health Association (APHA) 1989). Diatoms were identified after clearing in acid persulfate. The biovolumes of the more abundant taxa were estimated by measuring cell dimensions of at least 20 individuals and using the closest geometric formulae (Willen 1976). Integrated water samples (every $0.5 \mathrm{~m}$ ) of the littoral zone were collected at each of the four sampling sites with a Van Dorn bottle sampler. The total number of taxa and their frequency, were expressed as: $1=\leq 500,2=500-5,000,3=5,000-25,000$, and $4=25,000$ 100,000 cells/ 1 and were converted into percentages of each algal division. Diatom taxa were identified according to Patrick and Reimer (1975), while phytoplankton taxa were identified according to Wehr and Sheath (2001). Substrate samples (250 g) were also collected at each of the sampling sites, dried to constant weight $\left(105^{\circ} \mathrm{C}\right)$, cooled, and sieved to obtain particle size, while organic matter content was determined gravimetrically from $50 \mathrm{~g}$ test portions of unsieved material after ashing at $500^{\circ} \mathrm{C}$ for $8 \mathrm{~h}$.

\section{Sampling of cyanobacteria}

The method as described in Boyer et al. (2004) was used to sample cyanobacteria for determination of toxicity. Briefly, 6-1 samples were collected with a von Dorn sampler. The water was poured gently through 934 AH glass fiber filters in the field, frozen on dry ice, and returned to the laboratory in a cool holder for toxin analysis. Filters for toxin analysis were extracted by grinding with $10 \mathrm{ml}$ of $50 \%$ methanol containing $1 \%$ acetic acid and clarified by centrifugation. This extract was used for analysis of microcystins.

\section{Analysis of microcystins and geosmin}

The enzyme linked immunosorbent assay (ELISA), polymerase chain reaction (PCR), and protein phosphatase inhibition assay (PPIA) as described in Ueno et al. (1996) were used to screen potentially toxic strains of cyanobacteria and for routine analytical measurements of algal toxicity once a month over the period from November 2005 to February 2006. The presence of microcystin-LR was investigated at all four sampling sites, using an ELISA Quanti ${ }^{\mathrm{TM}}$ Kit for microcystins (Envirologix, USA). Results were obtained by reading the absorbance using a microtitre plate reader set (Thermo Labsystems, USA) at $450 \mathrm{~nm}$.

A Hewlett-Packard Model 6890 connected to a mass selective detector HewlettPackard Model 5972 was used for the analysis of geosmin within the surface water of 
all four sampling sites. Geosmin analytical standard was obtained from Wako (analytical grade, Japan). The procedure for the analysis of geosmin by headspace SPME was the same as prescribed by Watson et al. (2000). The method of Watson et al. (2000) regarding the operation of the GC, including injection port and carrier gas was followed in this study.

\section{Reference culture, extraction, and purification of DNA}

PCR analyses were conducted to determine the presence of the microcystin biosynthesis ( $m c y$ ) gene cluster in the field strain of cyanobacteria collected at Lake Krugersdrift. For these PCR analyses, the axenic M. aeruginosa strain PCC 7806 was used as a reference strain and cultured following the method of Oberholster and Botha (2007). The sample was then stored under vacuum until the DNA was extracted. DNA was extracted from the field-collected samples and the reference culture strain PCC 7806 using DNAzol ${ }^{\circledR}$ Genomic DNA Isolation reagent following the manufacturer's procedures (Molecular Research Center, Inc., USA).

\section{PCR amplification}

PCR amplification was performed with a GeneAmp2400 thermocycler (Perkin-Elmer Cetus, USA) following the method of Oberholster and Botha (2007). For analysis of the mcyA gene the primer set was as follows: McyA NMT (MSF: 5'ATCCAGCAGTTGAGCAAGC-3', 59 ${ }^{\circ} \mathrm{C}$; MSR: 5'-TGCAGATAACTCC GCAGTTG-3', 60 C; MSI: 5'-GAGAATTAGGGACACCTAT-3', 48 ${ }^{\circ} \mathrm{C}$ ) (Tillett et al. 2001). For analysis of the mcyB gene the primers sets was as follow: Tox 1P: 5'CGATT GTTACTGATACTCGCC-3', 57.9 C; Tox1M: 5'-TAAGCGGG CAGTTCCTGC-3', 58.2 ${ }^{\circ} \mathrm{C}$; Tox3P: 5'-GGAG AATCTTTCATGGCAGAC-3', 62. $4^{\circ} \mathrm{C}$; Tox1M: 5'-CCAATCCCTATCTA ACACAGTACCTCGG-3', 65.1 ${ }^{\circ} \mathrm{C}$; Tox7P: 5'-CCTCAGACAATCAACGGTTAG-3', 53.7 C; Tox3M: 5'-CGTGGATA ATAGTACGGGTTTC-3', 58.4 ${ }^{\circ} \mathrm{C}$; Tox10Pf: 5'-GCCTAATATAGAGCCATTGCC3', 59.8 ${ }^{\circ} \mathrm{C}$; Tox4Mr: 5'-CCAGTGGGTTAATTGAGTCAG-3', 57.9 ${ }^{\circ} \mathrm{C}$ ) (Oberholster 2004; Grobbelaar et al. 2004); McyB1-L: 5'-AGGCAAG CAGAAATTCAGGA-3', 55.9 ${ }^{\circ} \mathrm{C}$; McyB1-R: 5'-ATAGCAACCACCGTCAAAGG-3', 55.9 ${ }^{\circ} \mathrm{C}$; McyB3-L: 5'TCATCCCAACGTTG AACAAA-3', 55.2 ${ }^{\circ} \mathrm{C}$; McyB3-R: 5'CACCATATAAGCGGGCAGTT- $3^{\prime}, 55.2^{\circ} \mathrm{C}$ )(Botha-Oberholster and Oberholster 2007). For analysis of the mcyD gene the primer set was as follows: McyD-F2: 5'GGTTCGCCTGGTCAAAGTAA-3', 50 C; McyD-R2: 5'-CCTCGCTAA AGAAGGGTTGA-3', 50 ${ }^{\circ} \mathrm{C}$ ) (Kaebernick et al. 2000). PCR amplicons were analyzed by gel electrophoresis on $2 \%$ agarose.

\section{Chlorophyll $a$ and physico-chemical determinations}

Chlorophyll $a$ was extracted from lyophilized GF filters with $N, N$-dimethylformamide for $2 \mathrm{~h}$ at room temperature, and measured spectrophotometrically at 647 and $664 \mathrm{~nm}$ (Porra et al. 1989).

Nutrients - dissolved inorganic nitrogen (DIN) and soluble reactive phosphorus (SRP) - were analyzed spectrophotometrically according to the procedures published by the American Public Health Association (APHA), American Water Works Association (AWWA), and Water Pollution Control Federation (WPCF) (1980). Vertical profiles of water temperature, $\mathrm{pH}$, dissolved oxygen, and electrical conductivity were measured in the field with a Hach Sension ${ }^{\mathrm{TM}} 156$ portable multiparameter (Loveland, USA). The dissolved oxygen was measured at a point 
$3 \mathrm{~cm}$ above the substratum - between 10:00 and 18:00 $\mathrm{h}$ - when dissolved oxygen concentrations are generally highest (Ball and Bahr 1975). Dissolved oxygen readings were corrected for altitude and converted to percentage saturation. Transparency $(Z$ $\mathrm{SD}$ ) in the littoral zone was measured with a $20-\mathrm{cm}$ diameter, black and white quadrant Secchi disk, while light extinction was estimated using the light extinction coefficient $\left(k_{\mathrm{d})}\right.$ formula of Poole and Atkins (1929): $k_{\mathrm{d}}=1.7 / \mathrm{Z}_{\mathrm{SD}}$. This transformation provided data on the amount of light received by the phytoplankton in the littoral zone. During each sampling event, wind velocity was measured at each of the four sampling sites at a height of $1 \mathrm{~m}$ above the water surface with a Weather monitor 2 (Hayward, CA 94545, USA).

\section{Data analyses}

All data were recorded on standard Excel spreadsheets for subsequent processing and the statistical analysis was conducted using the SYSTAT ${ }^{\circledR} 7.0 .1$ software package

(SYSTAT 1997). Statistical differences were analyzed calculating Pearson correlation and a $t$ test using the Sigma Plot (Jandel Scientific) program. Values of $P \leq 0.05$ were regarded as significant.

\section{Results}

\section{Substrate conditions}

The substrate at the four sites was composed primarily of a mixture of small calcrete stones ( $1.5 \mathrm{~cm}$ in diameter), fine sand, and coarse silt, with approximately $30 \%$ of the mass represented by particles $<500 \mu \mathrm{m}$ in diameter. The average organic matter content from November 2005 to February 2006 of the substrate at sites 1 and 2 comprised $3.89 \%$ dry weight, which was higher than the value of $2.55 \%$ dry weight recorded for sites 3 and 4 .

\section{In-lake physical and chemical conditions}

The average water chemistry data for Lake Krugersdrift from November 2005 to February 2006 are shown in Table 1, and highlight the differences in water quality between sampling sites dominated by cyanobacterial scum (sites 1 and 2) and those without scum (sites 3 and 4). The sites without scum were slightly alkaline (pH 7.98.1) throughout the study, with relatively high concentrations of suspended solids (127-133 mg/l). Underneath the cyanobacterial scum at sites 1 and 2, average $\mathrm{pH}$ values tended to be slightly acidic ( $\mathrm{pH} 6.4-6.9)$. The lower $\mathrm{pH}$ values at sites 1 and 2 correlated negatively $(r=-0.93731 ; P \leq 0.01)$ with the lower average total alkalinity concentration $(132 \mathrm{mg} / \mathrm{l})$ for sites 1 and 2 during the cyanobacterial bloom. Similarly, the low average concentration of dissolved oxygen $(1.2 \mathrm{mg} / \mathrm{l})$ under the cyanobacterial bloom at sites 1 and 2 correlates negatively $(r=-0.99465 ; P \leq 0.05)$ with the high average concentration of microcystin-LR $(43.7 \mu \mathrm{g} / \mathrm{l})$ during the peak of the cyanobacterial bloom in December 2005 (Fig. 6). Furthermore, the high average concentrations of microcystin-LR at sites 1 and 2 during December 2005 also correlated strongly $(r=0.982297 ; P \leq 0.002)$ with the high average concentration of Chlorophyll $a(388 \mu \mathrm{g} / \mathrm{l})$ and high average cyanobacterial cell density $(r=0.999935$; $P \leq 0.001$ ) of $1.2 \times 10^{8} \mathrm{cells} / \mathrm{ml}$ (Fig. 6). The concentrations of soluble reactive phosphate and nitrate were high (Table 1) at all sampling sites throughout this study, confirming the eutrophic status of the waters of Lake Krugersdrift (Grobbelaar 1992). 
Table 1 Comparison of the average physical, chemical and biological characteristics recorded at four sampling sites in Lake Krugersdrift from November 2005 to February $2006(n=8)$

\begin{tabular}{|c|c|c|c|c|}
\hline Characteristic (units) & Site 1 & Site 2 & Site 3 & Site 4 \\
\hline $\begin{array}{l}\text { Electrical conductivity }\left(\mathrm{mS} \mathrm{m}^{-1} \text { at }\right. \\
\left.25^{\circ} \mathrm{C}\right)\end{array}$ & $76 \pm 4$ & $73 \pm 2$ & $77 \pm 6$ & $70 \pm 2$ \\
\hline $\mathrm{pH}\left(\right.$ Negative $\log \left[\mathrm{H}^{+}\right]$at $\left.25^{\circ} \mathrm{C}\right)$ & $6.4 \pm 0.8$ & $6.9 \pm 0.5$ & $7.9 \pm 0.6$ & $8.1 \pm 0.3$ \\
\hline Secchi disc reading $(\mathrm{m})$ & $0.25 \pm 0.07$ & $0.29 \pm 0.09$ & $1.18 \pm 0.4$ & $1.22 \pm 0.4$ \\
\hline $\begin{array}{l}\text { Light extinction coefficient }\left[k_{\mathrm{d}}\right] \\
\left(\mathrm{m}^{-1}\right)\end{array}$ & $6.8 \pm 0.2$ & $5.9 \pm 0.1$ & $1.4 \pm 0.2$ & $1.4 \pm 0.3$ \\
\hline Suspended solids (mg 1 ${ }^{-1}$ ) & $133 \pm 8$ & $131 \pm 6$ & $127 \pm 4$ & $131 \pm 3$ \\
\hline Dissolved oxygen $\left(\mathrm{mg} \mathrm{O}_{2} \mathrm{l}^{-1}\right)$ & $3.1 \pm 0.5$ & $2.9 \pm 1$ & $7.9 \pm 2.1$ & $7.3 \pm 2.2$ \\
\hline Sodium (mg Na $\left.{ }^{-1}\right)$ & $59 \pm 3$ & $59 \pm 5$ & $56 \pm 2$ & $59 \pm 1$ \\
\hline Potassium (mg K l$\left.~^{-1}\right)$ & $9.4 \pm 1$ & $9.8 \pm 1$ & $8.1 \pm 1.5$ & $9.3 \pm 1.3$ \\
\hline Calcium (mg Ca ${ }^{-1}$ ) & $42 \pm 2$ & $41 \pm 3$ & $42 \pm 3$ & $40 \pm 1$ \\
\hline Magnesium (mg Mg $\left.{ }^{-1}\right)$ & $24 \pm 2$ & $23 \pm 1$ & $24 \pm 4$ & $24 \pm 3$ \\
\hline Chloride (mg Cl ${ }^{-1}$ ) & $73 \pm 4$ & $79 \pm 1.5$ & $66 \pm 3$ & $71 \pm 2$ \\
\hline Sulfate $\left(\mathrm{mg} \mathrm{SO}_{4} \mathrm{l}^{-1}\right)$ & $17 \pm 2$ & $17 \pm 3$ & $16 \pm 3$ & $17 \pm 5$ \\
\hline Total alkalinity $\left(\mathrm{mg} \mathrm{CaCO}_{3} \mathrm{l}^{-1}\right)$ & $135 \pm 4$ & $129 \pm 3$ & $186 \pm 1.4$ & $194 \pm 1.2$ \\
\hline Silica (mg Si 1 $\left.{ }^{-1}\right)$ & $3.5 \pm 1$ & $2.9 \pm 3$ & $3.9 \pm 2$ & $4.1 \pm 2$ \\
\hline Nitrate $\left(\mathrm{mg} \mathrm{NO}_{3}-\mathrm{N} \mathrm{l}^{-1}\right)$ & $2.9 \pm 1$ & $2.1 \pm 0.5$ & $2.2 \pm 0.3$ & $1.9 \pm 0.9$ \\
\hline Orthophosphate $\left(\mathrm{mg} \mathrm{PO}_{4}-\mathrm{P} \mathrm{l}^{-1}\right)$ & $0.51 \pm 0.1$ & $0.47 \pm 0.2$ & $0.30 \pm 0.2$ & $0.39 \pm 0.1$ \\
\hline Temperature $\left({ }^{\circ} \mathrm{C}\right)$ & $22.1 \pm 2$ & $22.3 \pm 2$ & $21.7 \pm 3$ & $22.4 \pm 2$ \\
\hline $\operatorname{Geosmin}\left(\mu \mathrm{g} \mathrm{1^{-1 } )}\right.$ & $0.91 \pm 0.3$ & $0.73 \pm 0.6$ & $0.06 \pm 0.02$ & $0.03 \pm 0.04$ \\
\hline
\end{tabular}

The ionic dominance ratio for the lake water was

$\mathrm{Na}>\mathrm{Ca}>\mathrm{Mg} \geq \mathrm{K}: \mathrm{HCO}_{3} / \mathrm{CO}_{3}>\mathrm{Cl} \geq \mathrm{SO}_{4}$ and concentrations of total dissolved salts were moderately high (TDS $=360-415 \mathrm{mg} / \mathrm{l}$ ). The TDS concentrations of samples collected at sites 1 and 2 (beneath the cyanobacterial scum) were approximately $10 \%$ lower than the TDS values from sites 3 and 4, apparently due to the lower total alkalinity values at sites 1 and 2 (Table 1). There were slight differences between the average silica concentration at sites 1 and $2(3.2 \pm 1.5 \mathrm{mg} / \mathrm{l})$ and that of sites 3 and 4 $(4.0 \pm 2 \mathrm{mg} / \mathrm{l})$ throughout this study.

The average wind speed measured during the summer sampling campaign was $4.69 \mathrm{~m} / \mathrm{s}$, and the predominant wind direction was from the north-west to the southeast (Fig. 1). At this wind speed, and given the average fetch of the main basin of Lake Krugersdrift in the dominant wind direction $(4 \mathrm{~km})$, the wind mixed depth would have averaged approximately $8 \mathrm{~m}$. This is greater than the average depth of Lake Krugersdrift $(3.53 \mathrm{~m})$ and means that over $50 \%$ of the lake water column would be continuously mixed, promoting sustained sediment resuspension. The concentration of suspended solids in Lake Krugersdrift $(127 \pm 4-133 \pm 3 \mathrm{mg} / \mathrm{l}$; Table 2) remained moderately high during this study. The Secchi disc values for sites 1 and $2(0.25 \pm 0.07-0.29 \pm 0.09 \mathrm{~m})$ were noticeably lower than the readings obtained 
at sites 3 and $4(1.18 \pm 0.4-1.22 \pm 0.4 \mathrm{~m})$, and reflect the shading effect of the cyanobacterial scum that accumulated at sites 1 and 2 from November 2005 to February 2006. The shading effect of the dense cyanobacterial scum is also reflected in the corresponding average light extinction coefficient values $\left(k_{\mathrm{d}}\right)$ at sites 1 and 2 $\left(6.35 \pm 0.1 \mathrm{~m}^{-1}\right)$, compared to the average $k_{\mathrm{d}}$ value $\left(1.4 \pm 0.2 \mathrm{~m}^{-1}\right)$ at sites 3 and 4 . 
Table 2 A comparison of amplification products obtained after PCR analysis with different primers, as well as ELISA assay as determinants of toxicity, in strains of M. aeruginosa

\begin{tabular}{|c|c|c|c|c|c|c|c|c|c|c|c|c|}
\hline Strain & $\begin{array}{l}\text { Geographic } \\
\text { origin }\end{array}$ & $\begin{array}{l}\text { Primer } \\
\text { sets }\end{array}$ & & & & & & & & & & ELISA \\
\hline $\begin{array}{l}\text { M. aeru- } \\
\text { ginosa }\end{array}$ & & $\begin{array}{l}\text { McyB- } \\
\text { Tox3P/2 M }\end{array}$ & \begin{tabular}{|l} 
McyB- \\
Tox1P/1 M
\end{tabular} & $\begin{array}{l}\text { McyB- } \\
\text { Tox7P/3 M }\end{array}$ & $\begin{array}{l}\text { McyB- } \\
\text { Tox10P/4 M }\end{array}$ & $\begin{array}{l}\text { McyB1- } \\
\text { L/R }\end{array}$ & $\begin{array}{l}\text { McyB3- } \\
L / R\end{array}$ & $\begin{array}{l}\text { McyA- } \\
\text { MSR/MSF }\end{array}$ & $\begin{array}{l}\text { McyD- } \\
\text { F2/R2 }\end{array}$ & $\begin{array}{l}\text { McyA- } \\
\text { MSI }\end{array}$ & & \\
\hline PCC7806 & $\begin{array}{l}\text { The } \\
\text { Netherlands }\end{array}$ & + & + & + & + & + & + & + & + & + & + & \\
\hline UP37 & $\begin{array}{l}\text { Krugersdrift, } \\
\text { ZA (2004) }\end{array}$ & - & + & + & - & + & + & - & + & - & + & \\
\hline UP44 & $\begin{array}{l}\text { Krugersdrift, } \\
\text { ZA (2006) }\end{array}$ & - & + & + & + & + & + & - & + & - & + & \\
\hline
\end{tabular}

$+=$ positive/product; $-=$ negative/no product 


\section{Microcystins toxicity}

A dense cyanobacterial bloom $\left(1.41 \times 10^{6}\right.$ cells $\left./ \mathrm{ml}\right)$ was recorded at sites 1 and 2 during early November 2005 . This bloom reached a peak concentration of $1.2 \times 10^{8}$ cells $/ \mathrm{ml}$ at sites 1 and 2 in December 2005, before collapsing in late February 2006. The sampling period in this study coincided with a period of drought - rainfalls were below average across many parts of South Africa. Low rainfalls resulted in lower Modder River inflows to Lake Krugersdrift and water levels declined steadily due to evaporation. The scarcity of water prompted a reduction in water releases for irrigation; this reduced the wash-out of algae from the dam, and would have increased the concentrations of nutrients and dissolved salts. Lower water levels reduced the aerating effects of wind-mixing.

Toxin concentrations at sites 1 and 2 (measured with the ELISA technique) were variable throughout the sampling period (Fig. 6). An initially low average microcystin-LR concentration $(1.85 \mu \mathrm{g} / \mathrm{l})$ was recorded in early November 2005 , followed by a highly toxic peak concentration $(43.7 \mu \mathrm{g} / 1)$ during late December 2005 (Fig. 6) when M. aeruginosa dominated $\left(1.2 \times 10^{8}\right.$ cells $\left./ \mathrm{ml}\right)$ the phytoplankton community at sites 1 and 2 . The cyanobacterial bloom finally started to degrade at the end of February 2006 with a low microcystin-LR concentration of $0.51 \mu \mathrm{g} / 1$ at sites 3 and 4 , the microcystin-LR concentrations remained consistently below $0.38 \mu \mathrm{g} / 1$ throughout this study and can be ascribe to the low numbers of $M$. aeruginosa cells $(\leq 425$ cells/l) throughout the study period. PCR products obtained from all the $M$. aeruginosa strains collected at sites 1 and 2 indicated that these strains contained the microcystin toxin synthetase genes mcyB and mcyD of the microcystin biosynthesis ( $m c y)$ gene cluster, and therefore had the potential to produce cyanotoxins (Fig. 3 and Table 2).

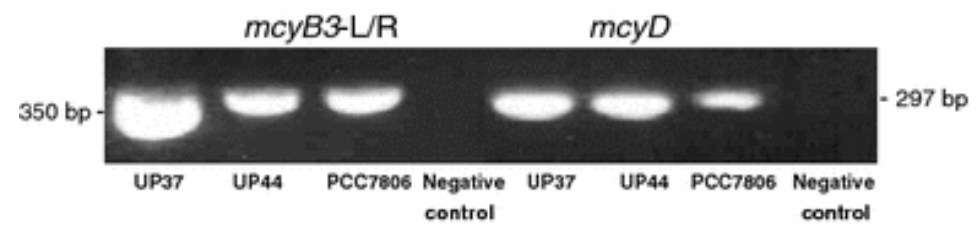

Fig. 3 Separation of PCR amplicons obtained after the PCR of M. aeruginosa strains UP37, UP44, and PCC7806

\section{Macroinvertebrates, phytobenthos, and functional feeding groups}

A total of 12 macroinvertebrate families were recorded from the four sampling sites in Lake Krugersdrift (Fig. 4). The macroinvertebrate populations at sites 1 and 2 (associated with the cyanobacterial scum) were characterized by a lower family abundance $(n=9)$ than at sites 3 and $4(n=10)$. Large numbers of leeches (Hirudinae) were present at sites 1 and 2 and these were the dominant family throughout the study (Berger and Parker Index, 0.470 and 0.445). There was a significant correlation $(r=0.973592 ; P \leq 0.001)$ between the specimen abundance $(n=279)$ of the Hirudinae family and the high concentrations of Microcystis cells $\left(1.2 \times 10^{8}\right.$ cells $\left./ \mathrm{ml}\right)$ during the peak of the cyanobacterial bloom at the end of December 2005, as well as through the duration of the study period. The dominant macroinvertebrate family throughout this study at sites 3 and 4 was Corixidae (Berger and Parker Index, 0.520 and 0.450). However, there was no correlation between the 
average specimen abundance of this family $(n=78)$ and the average low cell density ( $\leq 425$ cells/1) of Microcystis from late November 2005 to early February 2006. The macroinvertebrate family diversity from November 2005 to February 2006 at sites 3 and 4 were higher $\left(H^{\prime}=2.58 ; 2.79\right)$ and includes the families Coenagrionidae, Hydrophilidae, and Lymnaeidae that were not present at sites 1 and 2, where a lower family diversity $\left(H^{\prime}=2.16 ; 2.25\right)$ was observed for the same period of study time (Fig. 4).
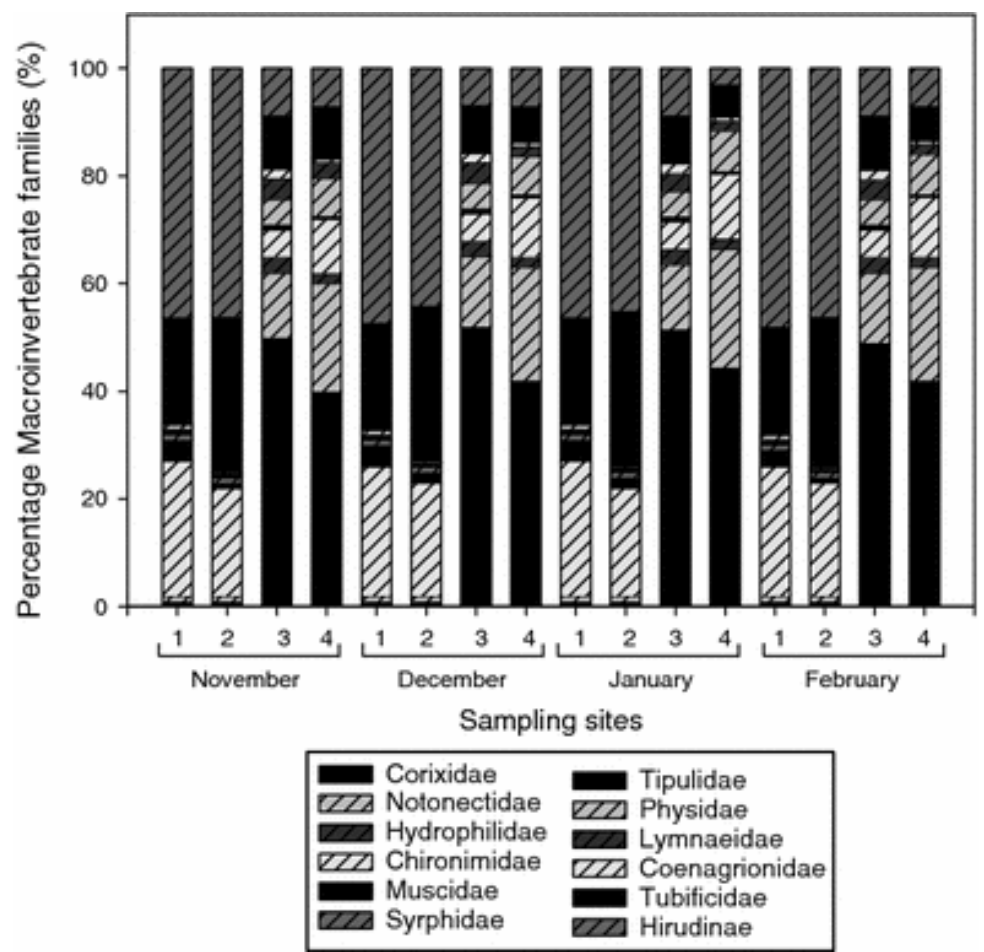

Fig. 4 Average abundance (\%) of macroinvertebrate families at four sampling sites in Lake Krugersdrift from November 2005 to February $2006(n=8)$

A large average abundance $\left(n=729 / \mathrm{m}^{2}\right)$ of collector-gatherers and predators were present at sites 1 and 2 throughout the study and their abundance correlated significantly $(r=0.990961 ; P \leq 0.001)$ with the physicochemical conditions of low dissolved oxygen $(3.1,2.7 \mathrm{mg} / \mathrm{l})$, and with the presence of abundant organic matter. A low average abundance $\left(n=11 / \mathrm{m}^{2}\right)$ of scrapers and shredders were present at sites 1 and 2 from November 2005 to February 2006. In contrast, far higher average abundance $\left(n=196 / \mathrm{m}^{2}\right)$ of scrapers and shredders were present at sites 3 and 4 and their abundance was positively correlated $(r=0.979174 ; P \leq 0.05)$ with the high abundance $\left(970\right.$ cells $\left./ \mathrm{cm}^{2}\right)$ of the epilithic alga Ulothrix zonata (Figs. 4, 5). 


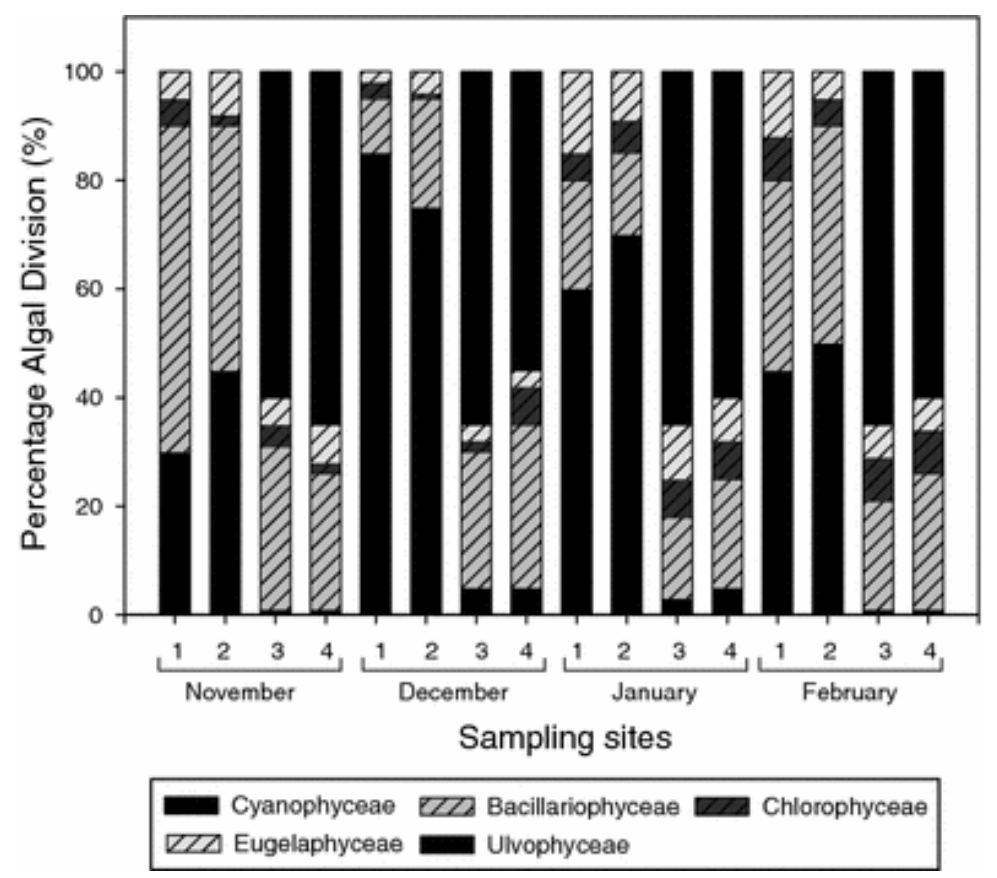

Fig. 5 Comparison of the algal populations (\%) at the four sampling sites in Lake Krugersdrift from November 2005 to February $2006(n=8)$

No aquatic macrophytes were present in the wave-washed littoral zone of Lake Krugersdrift. The average abundance of the epilithic alga $U$. zonata was 970 cells $/ \mathrm{cm}^{2}$ on the calcrete stones at the control sites 3 and 4, but was totally absent at the sites dominated by the cyanobacterial scum (1 and 2) from November 2005 to February 2006. A single species of diatom (Diatoma vulgare: $81 \%, 68 \%$ ) dominated the substrate at sites 1 and 2, while two other diatom species-Synedra acus (42\%) and Nitzschia acicularis (29\%) - dominated the substrate at sites 3 and 4. Phacus, Euglena, and Chlamydomonas species of the phytoplankton divisions Chlorophycea and Euglenophycea were occasionally identify in low numbers. These species are associated with eutrophic waters (Carter-Lund and Lund 1995) (Fig. 5).

\section{Discussion}

\section{Physico-chemical characteristics}

Many South African water storage reservoirs are shallow (mean depth less than $10 \mathrm{~m}$ ) and receive turbid river inflows. The combination of the turbid inflows and winddriven resuspension within the impounded water bodies ensure that these reservoirs remain turbid - from suspended solids rather than algal biomass - throughout the year (Allanson et al. 1990). The presence of high concentrations of suspended sediments in the water column reduces light penetration and tends to limit the growth of phytoplankton as well as benthic algae and aquatic macrophytes, even when high concentrations of nutrients are available (Allanson et al. 1990). Under these conditions, buoyant gas-vacuolate cyanobacteria are able to circumvent the light limiting effects of suspended sediments by occupying the upper part of the water column, adding to the light-shading effects of the suspended sediments and thereby 
gaining a competitive advantage over other phytoplankton species (Walmsley et al. 1980; Allanson et al. 1990). In Lake Krugersdrift high concentrations suspended solids were recorded throughout the study (average at all four sampling sites were $131 \pm 4 \mathrm{mg} / \mathrm{l}$ ) possibly due to the wind-induced particle resuspension which cause low Secchi disc readings $(\leq 1.5 \mathrm{~m})$. Furthermore concentrations of soluble reactive phosphate and nitrate were high (Table 1) at all sampling sites throughout this study, confirming the eutrophic status of the waters of Lake Krugersdrift (Grobbelaar 1992). It is known that the growth of diatoms can be inhibited by a low supply of silica. However, Willen (1991) reported that concentrations as low as $0.2 \mathrm{mg} \mathrm{l}^{-1}$-much less than measured in Lake Krugersdrift - should be sufficient for diatom reproduction and therefore seems not to be the reason for the low numbers of diatoms observed but rather the water hydrology (Willen 1991).

\section{Changes in the macroinvertebrate and phytobenthos communities}

Most freshwater benthos populations reach their maximum density and diversity in shallow water and decline with increasing depth in the profundal zone (Strayer 1985). This pattern appears to reflect a response to gradients of oxygen availability, habitat heterogeneity, and food resources, all of which are greater in the littoral zone of lakes (Thorp and Covich 2001).

There are two plausible explanations for the relatively low family abundance $(n=12)$ of macroinvertebrates at all four sampling sites in Lake Krugersdrift. Firstly, the high degree of fine inorganic sediment reduces the diversity of physical habitats, while decomposition of the trapped detritus would reduce the availability of oxygen (Allen 1995). In addition, the prolonged presence of relatively high concentrations of suspended solids (average $131 \pm 4 \mathrm{mg} / \mathrm{l}$ ) in Lake Krugersdrift can alter the habitat available to macroinvertebrates by reducing light penetration (and thereby preventing the growth of aquatic macrophytes) and smothering the sediment surface (Hellawell 1986). The second possible explanation for the relatively low abundance of macroinvertebrates is the presence of peptide hepatotoxins (such as microcystin) that have been released into the water column when cyanobacterial cells decompose. These toxins are extremely stable due to their chemical structure and persist for long periods in water. Kiviranta et al. (1991) reported that microcystin persisted for 23 months in cultures of Microcystis grown in water from the Vantaanjoki River, Finland. Under natural field conditions, these toxins are released from lysing cells over a prolonged period and pose a hazard to both vertebrates and invertebrates in aquatic ecosystems. Furthermore, the lethal effects of cyanobacteria to macroinvertebrates were confirmed in a whole-lake study conducted by White et al. (2005), who observed a decrease in total abundance and richness with an increase in Microcystis toxicity in Lake Elphinstone, Australia over a period of 3 months. The decrease in macroinvertebrate diversity (2.16 and 2.25) as observed at sites 1 and 2 , compared to sites 3 and 4 (2.58 and 2.79) correlated negatively with the high microcystin-LR values $(r=-0.99641 ; P \leq 0.01)$ and the low concentrations of dissolved oxygen beneath the cyanobacterial scum (Table 1 and Fig. 6). However, this phenomanon may have had a great adverse affect on the diversity of the macroinvertebrates distribution a sites 1 and 2. Scums of $M$. aeruginosa have been reported to dramatically attenuate incident light, reduce free gas exchange during decomposition, cause a decrease in $\mathrm{pH}$ values, increase soluble nutrient concentrations, and produce potentially toxic gases (Zohary 1985). Invertebrates differ both in their respiratory needs and in their anatomical and behavioural 
adaptations for obtaining oxygen. Many of the dominant macroinvertebrate taxa recorded at sites 1 and 2 are adapted to low levels of dissolved oxygen - for example, Oligochaeta (Tubificidae) are found in areas where oxygen supply can became reduced (Lang 1984). Furhermore, leeches (Hirudinae), which are primarily predators of macroinvertebrates (e.g., Oligochaeta and Gastropoda), can also withstand anaerobic conditions (Von Brand 1944). Sensitive taxa such as certain stoneflies, mayflies, and caddisflies have been recognized by other workers (e.g., Prat and Ward 1994) as indicators of good water quality; these taxa were absent from the littoral zone of Lake Krugersdrift.

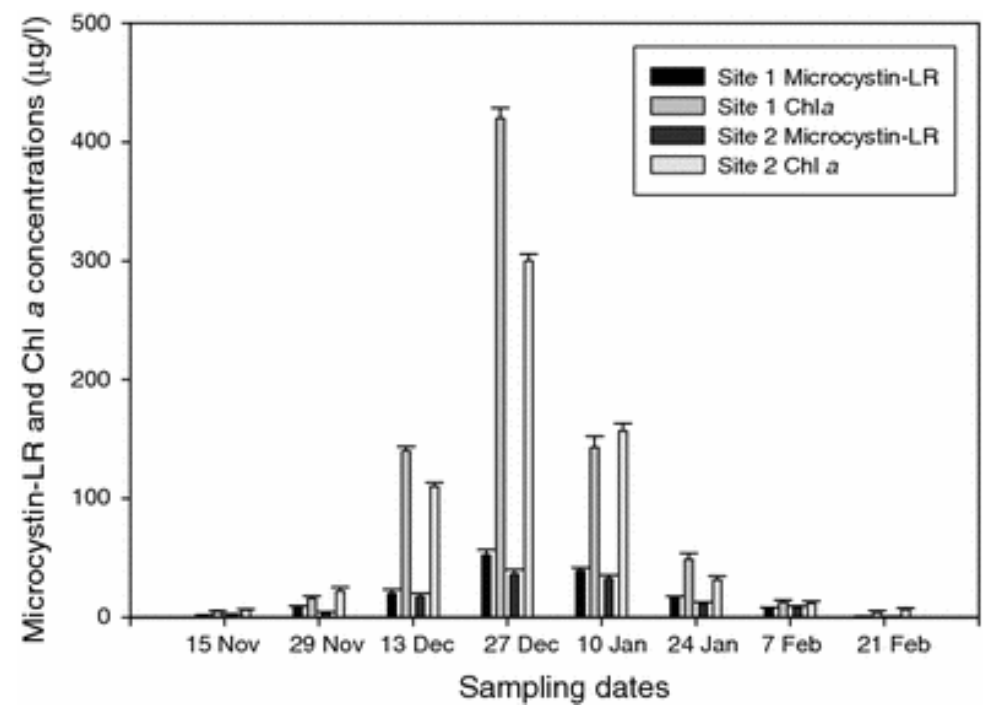

Fig. 6 Comparison of the intracellular microcystin-LR concentrations and chlorophyll $a$ contents at the four sampling sites in Lake Krugersdrift from November 2005 to February $2006(n=8)$

The ecological role of benthic algae stems from their position at the interface of abiotic and biotic lake components, and they are useful indicators of water quality and of current environmental conditions (Oberholster et al. 2005b). Similarly, information on phytoplankton species composition is important since the functional properties of algal assemblages vary strongly with species composition and phytoplankton also play a major role in the distribution of aquatic macroinvertebrates (Wehr and Sheath 2001).

We suggest that the presence of higher geosmin concentrations (Table 1) from the cyanobacterial bloom at sites 1 and 2, might account as one of the environmental factors for the absence of the epilithic $U$. zonata at these sites, as this compound have been implicated in reducing the growth of Chlorella pyrenoidosa (Ikawa et al. 2001). Alternatively, the low average light extinction coefficient $\left(k_{\mathrm{d}}\right)$ values of $6.35 \pm 0.1 \mathrm{~m}^{2}$ for sites 1 and 2 suggests that high concentration of cyanobacterial biomass - both suspended in the water column and concentrated at the water surface could have shaded out other phytoplankton. The lower $\mathrm{pH}$ values at sites 1 and 2 (compared to the $\mathrm{pH}$ values at sites 3 and 4-Table 1) are unlikely to be responsible for the absence of Ulothrix at sites 1 and 2, because Niyogi et al. (1999) reported that Ulothrix spp. could tolerate $\mathrm{pH}$ values below 4 in a Rocky Mountain headwater stream that received acidic mine drainage. 
In addition to their physical suppression of other algal species by light limitation, cyanobacteria have been reported to have direct toxic allelopathic effects on the growth and photosynthesis of phytoplankton (Bagchi et al. 1990; Sukenik et al. 2002). The reason for the noticeably higher numbers of the diatom $D$. vulgare at sites 1 and 2 (Fig. 5) may be due to the different $\mathrm{pH}$ values at these two sites, compared to the $\mathrm{pH}$ values recorded at sites 3 and 4 . Winter et al. (2003) reported that the presence of a higher proportion of diatom species was indicative of $\mathrm{pH}$ values above 7 , while a lower number of species was indicative of $\mathrm{pH}$ values below 7; this suggests that the structure of benthic diatom communities is closely linked to the $\mathrm{pH}$ of their environment. Further support for this has been provided by Kahlert and Andren (2005), who reported distinct differences in diatom community composition between streams with different $\mathrm{pH}$ regimes.

Reduced light levels associated with over-shadowing by the cyanobacterial scum, or toxicity (Oberholster et al. 2005a), provide additional possible explanations for the dominance of the diatom D. vulgare at sites 1 and 2 (Fig. 5). Gausch et al. (1998) reported that toxicity or enrichment with nutrients and/or organic material could cause a shift in the species dominance of algal communities in streams. Since it is known that diatoms in eutrophic water, like in the case of Lake Krugersdrift, can be inhibited by low supply of silica, however, this was not observed in the present study (Table 1).

\section{Substrate condition}

It is likely that a large portion of the higher organic matter content (3.89\% dry weight of the sediment) at sites 1 and 2 was contributed by decomposing cyanobacterial cell material. The higher organic matter content observed from November 2005 to February 2006 at sites 1 and 2 also correlated strongly $(r=0.996012 ; P \leq 0.005)$ with an increase in the average specimen abundance $(n=438)$ of collector-gatherers (Chironomidae and Oligochaeta) at these sites and with the high average specimen abundance $(n=415)$ of predators (Hirudinae) that prey on these organisms (Fig. 4).

\section{Cell density and toxicity of cyanobacterial bloom}

Microcystin concentrations (whole lake water with cells) — exceeding the WHO guideline of $1 \mu \mathrm{g} / \mathrm{l}$ for drinking water - were recorded where toxic cyanobacteria scums accumulated in the embayment close to the dam wall of Lake Krugersdrift (Fig. 6). The progressive accumulation of M. aeruginosa cells to form a scum in this embayment was the result of the positive buoyancy of Microcystis, the prevailing wind regime and the relative shelter from wind provided by the dam wall.

Not all strains of Microcystis produce toxins. Although all Microcystis strains possess genes for peptide synthetases, microcystin-producing, and non-toxic strains differ in the content of their genes for specific peptide synthetases (Meißner et al. 1996). An earlier study by Oberholster (2004) reported that one morpho-species Microcystis wesenbergii from Lake Rietvlei in South Africa lacked detectable microcystins and did not contain the $m с y B$ gene, one of the genes responsible for the activation and incorporation of Mdha, D-Ala, L-X, D-MeAsp, and L-Z of microcystins during biosynthesis (Tillett et al. 2001). In this study on Lake Krugersdrift we confirmed that the natural population of the genotype $M$. aeruginosa contains the $m c y B$ and $m c y D$ genes of the mcy gene cluster that produces microcystin (Fig. 3 and Table 2). 
Only molecular techniques are able to clarify which of the cyanobacterial genera and species in a given population is able to produce toxins, and these techniques are far more sensitive than most other chemical analysis techniques (Hisbergues et al. 2003). However, it is important to note that the cyanotoxins in Lake Krugersdrift do not only act as a potent stress factor in the lake's aquatic ecosystem. Cyanotoxins also pose a health hazard to humans because the raw water of Lake Krugersdrift is used to irrigate extensive areas of edible and forage crops downstream of the reservoir. Codd et al. (1999) reported that single cells of $M$. aeruginosa and the hepatotoxin microcystin were retained by salad lettuce after being sprayed with irrigation water containing microcystin-producing cyanobacterium. However, uptake by irrigated crops of cyanobacterial secondary metabolites can lead to biotransformation of toxin congeners, also promoting the possibility of oxidative stress in these plants (Wiegand and Pflugmacher 2005).

\section{Conclusion}

This study has demonstrated that macroinvertebrate diversity indices can be used successfully in South African lake assessments to compare changes in species composition between reference sites and those that have been adversely impacted by toxic cyanobacteria. Furthermore, we found that the continued presence of a toxic Microcystis scum in Lake Krugersdrift for a period of 4 months had clear, but subtle effects on the relative abundance of macroinvertebrates and phytoplankton, inhibiting the growth of some sensitive species and promoting the growth of tolerant ones. Ultimately, the adverse effects are propagated across all trophic levels within the reservoir. The sensitive enzyme-linked immunosorbent assay and polymerase chain reaction methods used in this study are proved to be a powerful means to identify microcystin-producing strains and toxicity in the cyanobacterial scum present in Lake Krugersdrift. These techniques therefore have the potential for use as an 'early warning system' for mass development of toxic cyanobacterial blooms. These assays therefore offer a useful opportunity to water resource managers who have to control water releases from the impoundment to downstream irrigation farmers. Crops that are spray irrigated with water containing toxic cyanobacterial populations from Lake Krugersdrift could pose a health risk to people and livestock that consume these crops. Therefore, knowledge of the location, extent, and toxicity of phytoplankton

blooms within the reservoir would allow the water resource manager to select a water withdrawal strategy that would minimize the risk posed by algal toxins in irrigation water.

\section{References}

Allanson BR, Hart RC, O'Keeffe JH, Robarts RD (1990) Inland waters of Southern Africa: an ecological perspective. Kluwer Academic Publishers, Dordrecht

Allen JD (1995) Stream ecology. Chapman and Hall, London, pp 1-338

American Public Health Association (APHA), American Water Works Association 
(AWWA), and Water Pollution Control Federation (WPCF) (1980) Standard methods for the examination of water and wastewater, 15th edn. American Public Health Association, Washington, DC

American Public Health Association (APHA) (1989) Standard methods for the examination of water and wastewater, 17th edn. American Public Health Association, Washington, DC

Bagchi SN, Palod A, Chaunan VS (1990) Algicidal properties of a bloom forming blue-green alga, Oscillatoria sp. J Basic Microbiol 30:21-29.

Ball RC, Bahr TG (1975) Intensive survey: Red Cedar River, Michigan. In: Whitton BA (ed) River ecology. Blackwell, Oxford, pp 431-460

Beattie KA, Kaya K, Codd GA (2000) The cyanobacterium Nodularia PCC 7804, of freshwater origin, produces [L-Har2] nodularin. Phytochemistry 54:57-61

Berger WH, Parker FL (1970) Diversity of planktonic Foraminifera in deep sea sediments. Science 168:1345-1347.

Botha-Oberholster A-M, Oberholster PJ (2007) PCR based markers for detection and identification of toxic cyanobacteria. WRC Report No. 1502/1/07. Water Research Commission, Pretoria, pp 1-58

Boyer GL, Satchwell MF, Shambaugh A, Watzin M, Mihuc TB, Rosen B (2004) The occurrence of cyanobacterial toxins in Lake Champlain Waters. In: Manley T, Manley P, Mihuc TB (eds) Lake Champlain: partnerships and research in the new millennium. Kluwer Academic Press, Dordrecht, pp 241-257

Carmichael WW (1994) The toxins of cyanobacteria. Sci Am 270:78-86

Carter-Lund H, Lund JWG (1995) Freshwater algae - their microscopic world explored. Biopress Ltd, pp 1-360

Chong MWK, Wong PKS, Shaw GR, Seawright AA (2002) Toxicity and uptake mechanism of cylindrospermopsin and lophyrotomin in primary rat hepatocytes. Toxicon 40:205-211.

Codd GA, Metcalf JS, Beattie KA (1999) Retention of Microcystis aeruginosa and microcystin by salad (Lactuca sativa) after spray irrigation with water containing cyanobacteria. Toxicon 37:1181-1185.

Figueredo CC, Giani A (2001) Seasonal variations in the diversity and species richness of phytoplankton in a tropical eutrophic reservoir. Hydrobiologia 445:165174. 
Gausch H, Ivorra N, Lehmann V, Paulsson M, Real M, Sabater T (1998) Community composition and sensitivity of periphyton to atrazine in flowing waters: the role of environmental factors. J Appl Phycol 10:203-213.

Grobbelaar JU (1985) Phytoplankton productivity in turbid waters. J Plankton Res $7: 653-663$.

Grobbelaar JU (1992) Nutrient versus physical factors in determining the primary productivity of waters with high inorganic turbidity. Hydrobiologia 238:177-182.

Grobbelaar JU, Botes E, Van den Heever JA, Botha A-M, Oberholster PJ (2004) Scope and dynamics of toxin produced by cyanophytes in the freshwaters of South Africa and the implications for human and other users. WRC Report No: 1029/1/04. Water Research Commission, Pretoria, pp 1-9

Hellawell JM (1986) Biological indicators of freshwater pollution and environmental management. Elsevier Applied Science, London

Hisbergues M, Christiansen G, Rouhiainen L, Sivonen K, Börner T (2003) PCRbased identification of microcystin-producing genotypes of different cyanobacterial genera. Arch Microbiol 180:402-410.

Ikawa M, Sasner JJ, Haney JF (2001) Activity of cyanobacterial and algal odor compounds found in lake waters on green alga Chlorella pyrenoidosa growth. Hydrobiologia 443:19-22.

Kaebernick M, Dittman E, Börner T, Neilan BA (2000) Multiple alternate transcripts direct the biosynthesis of microcystin, a cyanobacterial non-ribosomal peptide. Appl Environ Microbiol 68:449-455.

Kahlert M, Andren CM (2005) Benthic diatoms as valuable indicators of acidity. Verh Int Verein Limnol 29:635-639

Kiviranta J, Sivonen K, Lahti K, Luukkainen R (1991) Production and biodegradation of cyanobacterial toxins - a laboratory study. Arch Hydrobiol 121:281-294

Lang C (1984) Eutrophication of Lake Leman and Neuchatel (Switzerland) indicated by oligochaete communities. Hydrobiologia 114:131-138.

MacKintosh RW, Dalby KN, Campbell DG, Codd GA (1990) Cyanobacterial microcystin-LR is a potent and specific inhibitor of protein phosphatases 1 and $2 \mathrm{~A}$ from both mammals and higher plants. FEBS Lett 264:187-192. 
Meißner K, Dittmann E, Börmer T (1996) Toxic and non-toxic strains of the cyanobacterium Microcystis aeruginosa contain sequences homologous to peptide synthetase genes. FEMS Microbiol Lett 135:295-303.

Merrit RW, Cummins KW (1996) An introduction to the aquatic insects of North America, 3rd edn. Kendal/Hunt, Dubuque, Iowa, USA

NIWR (National Institute for Water Research) (1985) The limnology of Hartbeespoort dam. South African National Scientific Programmes Report No. 110. Foundation for Research Development, Pretoria

Niyogi DK, McKnight DM, Lewis WM (1999) Influences of water and substrate quality for periphyton in a Montana stream affected by acid mine drainage. Limnol Oceanogr 44:804-809

Oberholster PJ (2004) Assessing genetic diversity and identification of Microcystis aeruginosa strains through AFLP and PCR-RFLP analysis. M.Sc. Thesis, University of the Free State, Bloemfontein, South Africa, pp 1-114

Oberholster PJ, Botha A-M (2007) Use of PCR based technologies for risk assessment of a winter cyanobacterial bloom in Lake Midmar, South Africa. Afr J Biotechnol 6:1794-1805

Oberholster PJ, Botha A-M, Cloete TE (2005a) An overview of toxic freshwater cyanobacteria in South Africa with special reference to risk, impact and detection by molecular marker tools. Biokem 17:57-71

Oberholster PJ, Botha A-M, Cloete TE (2005b) Using a battery of bioassays, benthic phytoplankton and the AUSRIVAS method to monitor long-term coal tar contaminated sediment in the Cache la Poudre River, Colorado. Water Res 39:49134924.

Patrick R, Reimer CW (1975) The diatoms of the United States exclusive of Alaska and Hawaii, vol 2. National Academy of Sciences, Philadelphia, USA Part 1. Monograph 13

Pitois S, Jackson MH, Wood BJB (2001) Sources of the eutrophication problems associated with toxic algae: an overview. J Environ Health 64:25-32

Poole HH, Atkins WRG (1929) Photo-electric measurements of submarine illumination throughout the year. J Mar Biol Assoc UK 16:297-324

Porra RJ, Thompson WA, Kriedemann PE (1989) Determination of accurate extinction coefficients and simultaneous equations for assaying chlorophyll $a$ and $b$ extracted with four different solvents: verification of the concentration of chlorophyll 
standards by atomic absorption spectrometry. Biochim Biophys Acta 975:384-394.

Prat N, Ward JV (1994) The tamed river. In: Margalef R (ed) Limnology now: a paradigm of planetary problems. Elsevier Science B.V.,Amsterdam, The Netherlands, pp 219-236

Republic of South Africa (1998) The National Water act (Act No. 36 of 1998) Government of the Republic of South Africa, Pretoria, South Africa

Rondel C, Arfi R, Corbn D, le Bihan F, Hadji Ndour E, Lazzaro X (2008) A cyanobacterial bloom prevents fish trophic cascades. Freshw Biol 53:637-651.

Shannon CE, Weaver W (1949) The mathematical theory of communications. University of Illinois Press, Urbana

Strayer D (1985) The benthic micrometazoans of Mirror Lake, New Hampshire. Arch Hydrobiol 72:287-426

Sukenik A, Eshkol RL, Hadas O (2002) Inhibition of growth and photosynthesis of the Dinoflagellate Peridinium gatunense by Microcystis sp. (cyanobacteria): a novel allelopathic mechanism. Limnol Oceanogr 47:1656-1663

SYSTAT (1997) Systat $^{\circledR}$ 7.0.1 for Windows ${ }^{\circledR}$ : Statistics. SPSS Inc, Chicago, USA

Thorp JH, Covich AP (2001) Ecology and classification of North American freshwater invertebrates. Academic Press, San Diego, California, USA, pp 1-775

Tillett D, Parker DL, Neilan BA (2001) Detection of toxigenicity by a probe for the microcystin synthetase A gene (mcyA) of the cyanobacterial genus Microcystis: comparison of toxicities with 16S rRNA and phycocyanin operon (phycocyanin intergenic spacer) phylogenies. Appl Environ Microbiol 67:2810-2818.

Ueno Y, Nagata S, Tsutsumi T, Hasegawa A, Yoshida F, Suttajit M et al (1996) Survey of microcystins in environmental water by a highly sensitive immunoassay based on monoclonal antibody. Nat Toxins 4:271-276

Van Ginkel CE (2004) A national survey of the incidence of cyanobacterial blooms and toxin produced in major impoundments. Internal Report No. N/000/00/DEQ/0503. Resource Quality Services, Department of Water Affairs and Forestry, Pretoria, pp 1-44

Van Ginkel CE, Hohls BC, Belcher E, Vermaak E, Gerber A (2001) Assessment of the Trophic Status Project. Internal report No. N/0000/00/DEQ/1799. Institute for Water Quality Studies, Department of Water Affairs and Forestry, Pretoria, pp 1-334 
Van Ginkel CE, Silberbauer MJ, Vermaak E (2000) The seasonal and spatial distribution of cyanobacteria in South African surface waters. Verh Int Verein Limnol 27:871-878

Voelz NJ, Ward JV (1991) Biotic responses along the recovery gradient of a regulated stream. Can J Fish Aquat Sci 48:2477-2490.

Von Brand T (1944) Occurrence of anaerobiosis among invertebrates. Biodynamica $4: 185-328$

Walmsley RD, Butty M, Van Der Piepen H, Grobler DC (1980) Light penetration and the interrelationships between optical parameters in a turbid subtropical impoundment. Hydrobiologia 70:145-157.

Watson SB, Brownlee B, Satchwill T, Hargesheimer EE (2000) Quantitative analysis of trace levels of geosmin and MIB in source and drinking water using headspace SPME. Water Res 34:2818-2828.

Wehr JD, Sheath RG (2001) Freshwater algae of North America, ecology and classification. Academic Press, San Diego, USA, pp 775-804

White SH, Duivenvoorden LJ, Fabbro LD (2005) Impacts of a toxic Microcystis bloom on the macroinvertebrate fauna of Lake Elphinstone, Central Queensland, Australia. Hydrobiologia 548:117-126.

Wiegand C, Pflugmacher S (2005) Ecotoxicological effects of selected cyanobacterial secondary metabolites - a short review. Toxicol Appl Pharmacol 203:201-218.

Willen E (1976) A simplified method of phytoplankton counting. Br Phycol J 11:265278.

Willen E (1991) Planktonic diatoms - an ecological review. Algol Stud 62:69-106 Stuttgart, Augustus 1991

Winter JG, Dillon PJ, Paterson C, Reid RA, Somers KM (2003) Impacts of golf course construction and operation on headwater streams: bioassessment using benthic algae. Can J Bot 81:848-858.

Zohary T (1985) Hyperscum of the cyanobacterium Microcystis aeruginosa in a hypertrophic lake (Hartbeespoort Dam, South Africa). J Plankton Res 7:399-409. 